\title{
Believers or loyalists? Identity and social responsibility of Jesus communities in the Empire
}

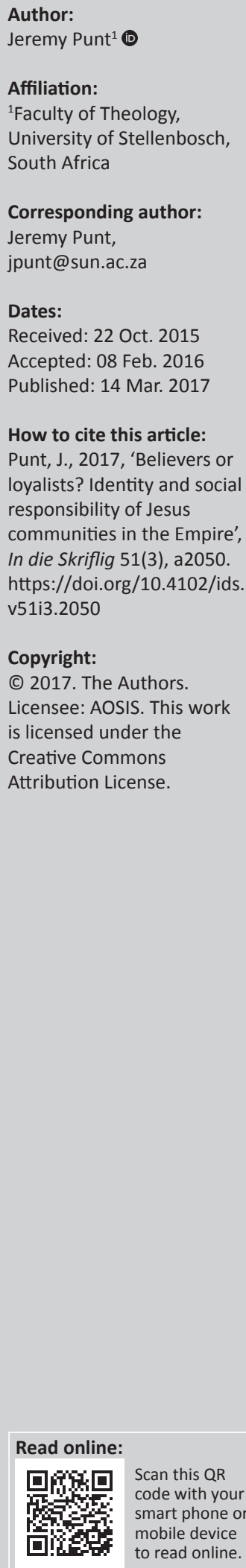

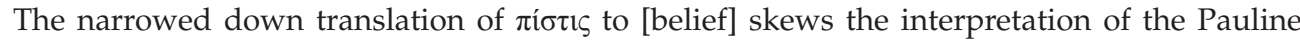
letters, where this word-group primarily denotes loyalty and fidelity, including notions of trust, confidence and conviction. These notions, if in different ways, framed the Jesus communities' relationship to God as well as to the imperial context in significant ways. In the end, rather than faithful discipleship and responsible citizenship, the Pauline letters promoted faithful citizenship.

\section{Introduction}

Paul introduced the notion of citizenship in the New Testament. ${ }^{1}$ Some would argue that this is no particular achievement since Paul's letters are the oldest writings in the New Testament and therefore any theme he placed on the table would have been a first. From the range of themes, ideas and metaphors he could have chosen for describing the lives of Jesus followers, his choice for a concept with political implication is significant and worthy of investigation. Paul used citizenship notions that were part of a politically charged discourse at the time within which it

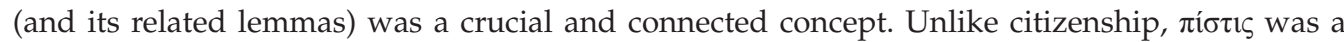
word Paul often used. It resonated across a broader spectrum of meaning in the 1st century than its univocal translation in the Bibles as 'faith' or 'belief'.

Claims regarding political nuances in Paul's writings are not difficult to substantiate, but they are somewhat ambivalent, given the context. Politics and religion were simply not such categorically divided notions as modern people generally hold them to be - another topic receiving attention below. Furthermore, citizenship often was a sought after commodity, not taken for granted as much as legitimate childhood. Still, sonship in particular, was not simply the outcome of birth. So too, citizenship was not simply about birth or residence in a certain place. Intimations in the Pauline letters regarding responsible citizenship, on the one hand, are not focussed on keeping the polity honest, but indicate rather a sceptical and resistant attitude towards the authorities of the day. On the other hand, New Testament authors can be shown to have availed themselves of imperialist discourse, taking it over for their own purposes. This article investigates faithful discipleship - as shorthand for life in Christ ${ }^{2}$ - and responsible citizenship in the Pauline letters, which evidently did not exist independently of one another. These notions were tied up in socioideological discourse of the time, but through translations and rather one-sided theological readings made to disappear from view. My argument is that, rather than faithful discipleship and responsible citizenship, the Pauline letters show a rhetoric of faithful citizenship!

\section{1st century citizenship}

Assuming a linguistic frame of reference, entirely informed by an ecclesial context, is anachronistic, since Paul's letters pre-date Christianity, formal church structures and orthodoxy. In fact, 'Paul's words are not church words, religious-theological words, but vocabulary in common civic discourse, frequently with critical political edges' (Zerbe 2012:15). The proper setting for

1.The Pauline use of citizenship, directly and indirectly if sparsely, requires attention for this choice of terminology. The kingdom or kingdom of God/Christ's language, so prevalent in the gospels, is also present in the Paul letters (8 times: Rm 14:17; 1 Cor 4:20, 6:9-10 15:24, 50; GI 5:21; 1 Th 2:12; and six times in the deutero-Paulines: Eph 5:5; Col 1:13, 4:11; 2 Th 1:5; 2 Tm 4:1, 18). However, limitations in scope do not allow exploration of the possible juxtaposition between citizen and kingdom terminology here. Suffice it to point out that, unlike citizenship's close association to the contemporary New Testament world the focus of God's kingdom terminology was that, unike eschatologi [that] underlies the whol of his teaching'). Paul's idos on 'civic life' do not come in a treatise-like handling of the topic. perspective [that undic he addressed impacted on their civic lives - partly also through invoked terms and concepts relating to civic life in his theological considerations and moral exhortation.

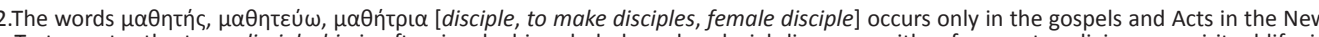
Testament - the term discipleship is often invoked in scholarly and ecclesial discourse with reference to religious or spiritual life, in contrast with citizenship, secular life including notions of broader social responsibilities. 
Paul's emphasis on $\pi$ í $\tau \iota \varsigma$ was the commonwealth or citizenship. In other words, citizenship gave content and meaning also to Pauline appeals to $\pi i ́ \sigma \tau \iota \varsigma$. When Paul therefore encouraged recipients of his letters in Galatia, Philippi or Rome to exercise a certain kind of citizenship, people heard a concept they were very familiar with and that determined their lives from long before they ever heard of Paul.

\section{Citizenship, Paul and Roman times}

The value of Roman citizenship largely derived from the benefits attached to it, compared to non-citizens. ${ }^{3}$ Developments in the Hellenistic period already saw citizenship gain a more technical political significance which it did not have earlier. With the Greeks the city became a political entity and citizenship started to involve carefully protected privileges. ${ }^{4}$ This trend continued in Roman times. ${ }^{5}$ Roman citizenship built on archaic and classical Mediterranean traditions, but was, nevertheless, unusual in comparison to the Persians and others who identified people as subjects rather than as citizens (Woolf 2012:27). Woolf (2012) further notes that:

The crucial point is that Romans did not use citizenship as a way of creating a hard boundary between themselves and aliens. Instead they used the language of citizenship to express a set of statuses and relationships through which individuals might be involved in the community in different ways, and also to various degrees. (p. 220)

Initially, Roman citizenship was restricted to Rome, but in imperial times it was extended shrewdly to non-Romans for services in the interest of Rome. Roman citizenship was a special distinction and retained in the family, transmitted by birth (Bruce 1992:1048). ${ }^{6}$ Although Paul, in his letters, never claimed Roman citizenship, it is expressly indicated in Acts:? Paul claimed as Jewish man his Roman citizenship in Tarsus

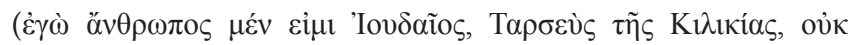

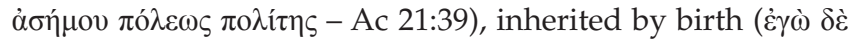

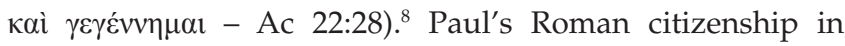
Acts does not sit well with the autobiographical sections in his letters where it is never mentioned. Regardless of his

3.Ancient Near Eastern citizenship generally only meant birth or residence in a particular location, with freeborn men only entitled to a modicum of privileges if any. Special prestige accrued to citizens of prominent cities (for Jerusalem, see Ps 87; Bruce 1992:1048).

4.In 5th century Athens, both parents had to be freeborn Athenians for a child to be considered as citizen (see Arist. Ath. Pol. 26).

5.The value and exclusivity of Roman citizens' privileges waned throughout the 2nd century, and came to an end when Caracalla granted it to all freeborn provincials throughout the Empire (Bruce 1992:2040; cf. Perkins 2009:5; Woolf 2012:219)

6. Roman citizen claims could be validated by birth registers, as the Lex Aelia Sentia (4 CE) and the Lex Papia Poppaea (9 CE) provided for the registration of Roman citizens at birth. The child's father received a copy of the entry, which the mature child apparently sometime wore around the neck or was kept in the family archives (Bruce 1992:1048-1049).

7.On three occasions Acts has Paul exercising his right as Roman citizen: protesting his beating without a fair trial in the Roman colony of Philippi (16:37); averting a flogging by Roman authorities in Jerusalem (since Valerian and Porcian laws prohibited interrogation under torture for Roman citizens) (22:25); and appealing to Caesar in Caesarea for having his case transferred to the supreme tribunal in to Caesar in Caes
Rome $(25: 11)$.

8.In the 1st century, a property qualification of 500 drachmae was required for citizenship in Tarsus (see Dio Chrys. Or. 34.23). personal standing, he referred to citizenship explicitly, particularly in his letter to Philippi (e.g. Phlp 3:20) and other times, he suggested the concept (e.g. Gl 4:25-26). Paul's deployment of citizenship, in close concert with terms like $\pi i ́ \sigma \imath \varsigma$, require further analysis.

\section{Gods, rulers and humans}

Citizenship often proved to be the link between people and gods in antiquity. For ancient people, religion was thought of in terms different from modern categories. The importance of religion was connected directly to ethnic ties and the antiquity of religion; meeting the obligations of your people's gods; participating or at least showing respect to public cult activities; and, last but not least, 'the importance for public security of maintaining the pax deorum, the concordat between heaven and earth that guaranteed the well-being of city and empire' (Fredriksen 2006:601). ${ }^{9}$ Such connections rested on the family type relationships that people, as part of larger groups, saw themselves having with gods. Family relationships with gods depended on descent. Thus, kings of Israel such as Alexander the Great and various emperors were deemed the 'son' of some god. ${ }^{10}$ Hellenistic and Roman representatives constructed intricate relational webs between cities through appeals to kinship established through deities. ${ }^{11}$ Fredriksen (2006:591) laconically remarks, 'Divine connections were politically useful.'

Paul was familiar with references to the Israelites as the sons of their God. Interestingly, when he took up the notion of Israel's divine Sonship, he further differentiated his genos in

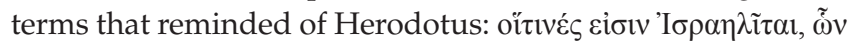

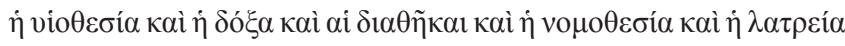

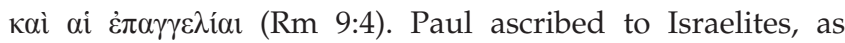
gracious gift of their God, inter alia three aspects: the deity's presence expressed by $\dot{\eta} \delta$ ó $\xi \alpha$ or glory invoking divine

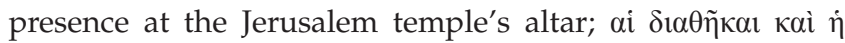
vo $\mu$ o $\theta \varepsilon \sigma i \alpha$ or customs in the sense of covenant and Torah; and $\dot{\eta} \lambda \alpha \tau \rho \varepsilon i ́ \alpha$ or cult which again reference the Temple's cultic actions. $^{12}$

The close relationship between people and their gods had a number of implications. Firstly, gods and their human followers regularly came in contact with each other. By simple equation, the greater the political unit, the greater the diversity and plurality of people and their gods. Diversity of gods and peoples meant a corresponding

9.Also at a broader level, surpassing rule over a city to rule over the world, religious notions were vital: 'Essentially a religious concept already in pagan times, the ideal of world unity became extremely forceful when imperialism and monotheism joined hands' (Strootman 2014:38).

10.'Alexander was descended from Heracles and the Julian house, through Aeneas, from Venus. Jewish scriptures used similar language, designating Israelite kings the sons of Israel's god (e.g. $2 \mathrm{Sm} 7: 14$; Ps 2:7, and frequently elsewhere. Later Christian exegesis referred such passages to Jesus)' (Fredriksen 2006:590-591).

11.'We hear much of such elite $\gamma \varepsilon \dot{v \eta}$ in the Roman period, since Rome extended its rule over the Greek world by forging alliances between its aristocracy and the Greek elites' (Stowers 1995:317).

12.Gentile-Christian communities of the 2 nd and 3rd centuries used such Mediterranean language of divinity and blood-kinship (ethnicity) to formulate their identity (Buell 2002:429-468). 
diversity of cultic practices. ${ }^{13}$ Secondly, people assumed the existence of many different gods given the existence of many different people and therefore the existence of outsiders' gods was not problematic. Paul, too, accepted the existence and influence of other gods, but insisted that, in order to be included in the coming redemption, they should worship only Israel's God and not others (2 Cor 4:4; Gl 4:8-9; 1 Cor 15:24). Thirdly, the register for cult respectability within the 1st-century Mediterranean world was precisely ethnicity and antiquity (Fredriksen 2006:592).

Within the wide range of deities and cultic activities, two institutions held the diversity of gods, cults and peoples together. In the 1st century Roman world, the role of emperor worship amidst the plurality of religions or cults, should not be underestimated, because, as Fredriksen (2006:592) argues, 'the dense religious multiplicity of the Roman world was offset by the binding power of civic organization and the imperial cult' ${ }^{14}$ The two institutions derived from Alexander the Great whose Greek city notion left its mark on Roman religion and also on politics. Cities were little short of being religious institutions, as inhabitants displayed their loyalty through public and communal rituals (processions, blood sacrifices, dancing, hymns, athletic and musical competitions) to the cities' heavenly patrons to safeguard their favour. In short, the connection between gods and cities meant that the well-being and, indeed, prosperity of a city, depended on its inhabitants, showing due deference and respect to the gods, if not worshipping them. ${ }^{15}$ Conversely, citizenship and emperor worship played a crucial role in the stability of 1stcentury life: gods were as important to cities' well-being as citizenship was for maintaining social cohesion. ${ }^{16}$

\section{Politics and religion: two sides of the same coin}

Citizenship served as the link between people and gods in antiquity and was (to use modern categories) both a political and religious concept. The close relationship between gods, rulers and people in ancient times underscores that in the

13.Fredriksen (2006:591) point out that, notwithstanding a wide range of religious practices present in ancient empires, it did not constitute what today would be seen as religious tolerance: 'Ancient society simply presupposed religious difference, since many subject peoples eo ipso meant many customs and many gods', and as Strootman (2014:56) argues, 'Religious syncretism enhanced this notion of imperial commonalty.' Lipka (2009:192) is of the opinion that 'lack of spatial focalization, ritual simplicity, and self-sufficiency with regard to functiona focalization' were three decisive reasons for the later rise of Christianity in its polytheistic context.

14.' [ $T$ ] he cult of the ruler, introduced to the West through Alexander, was adapted and adopted by Rome. The emperors, from Augustus on, ruled and protected the commonwealth as heaven's special agent on earth. After death, translated to a higher realm, they continued to serve as the empire's special agent in heaven ... Such worship served to bind the empire's far-flung municipalities together both politically and religiously... Politically, establishing an imperial cult brought honor politically and religiously ... Politically, establishing an imperial cult brought honor to one's city and the potential for more direct imperial patronage. Religiously, to
offer to the emperor was to offer as well for the empire' (Fredriksen 2006:593). The offer to the emperor was to offer as well for the empire' (Fredriksen 2006:593). The
diversity in emperor worship and the tendency to superimpose emperor worship diversity in emperor worship and the tendency to superimpose emperor worship
upon other existing cults, make the use of the plural, cults, advisable when referring to emperor worship.

15.Tertullian's famous remark towards the end of the 2nd century CE, shows this tension in early Christian practice: 'If Tiber overflows, and Nile does not; if heaven stands still and withholds its rain, and the earth quakes; if famine or pestilence take their marches through the country, the word is, Away with these Christians to the lion!' (Apol. 40.2; http://www.tertullian.org/articles/reeve_apology.htm).

16.In later years, probably as the early Christian church and Empire grew closer together, the distinction became less clear - also with regard to emperor worship. 'And as canons 2, 3, and 4 of the Council of Elvira ( $303 \mathrm{CE}$ ) make clear, not all gentile Christians saw the problem: this church council had to legislate against Christians who nonetheless continued to serve as flamines, that is, as priests of the imperial cult' (Fredriksen 2006:302) 1st-century politics was not conceived of as a separate sphere in contra-distinction to economics, religion or culture. 'Particularly in the Roman Empire, politics and religion were not only intimately connected, but arguably the same thing ${ }^{\prime 17}$ (Hollingshead 1998:x). This scenario did not mean a level playing field on which many disparate, fledgling, often disjointed communities of Jesus followers (which should not all too easily be assimilated under the rubric 'early Christianity') came into contact with the generally well-oiled, but in any case overwhelming and vast machinery of the Imperium, deployed with its military, social and religious dimensions across the ancient Mediterranean. In fact, with the intimate connection between politics and religion, the competition between Empire and church for the submission, obedience or loyalty (the $\pi i ́ \sigma \tau \varsigma$ ) of 1st-century people, set the scene for a power struggle; even if during New Testament times it was a muted affair given the comparative size of Jesus-follower communities. ${ }^{18}$

The challenges raised by the Roman Empire and emperor cults for other religious formations and practices such as the early Jesus-follower communities, was that religion was predominantly accomplished through public participation in rituals. 'The ritual was what mattered, rather than any doctrinal or theological rationale' (Bryan 2005:117). This awareness requires caution for a construct such as 'Roman imperial theology' (see Crossan \& Reed 2004:10) - even if its constructed nature is admitted. Officially sanctioned ritual activities constituted religion in the eyes of the Romans. Notwithstanding some 'theological reflection' (e.g. Cicero's On the nature of the gods; see also Versnel 2011), religious rites were that which constituted religious reality for the general populace. $^{19}$

For what today is seen as religion, the word cult, then, is the better term in the 1st-century Mediterranean world: 'those rituals and offerings whereby ancients enacted their respect for and devotion to the deity, and thereby solicited heaven's good will'. Individual households and even individuals practiced their own versions of piety, but ancient worship was generally public, communal and political (at civic and imperial levels). While modern religion focuses on 'psychological states', 'sincerity or authenticity of belief' or the inner disposition of the believer, ancient religion focused on acts: 'how one lived, what one did, according to both inherited and local custom. Ancient religion was this intrinsically communal and public performance-indexed piety' (Fredriksen 2006:590).

17.The notions we label as "theological' or "political" and, especially, the attempts to maintain a distinction between them would not have been understood in the 1st century CE. 'The attempt to suggest a division here between the 'religious' and the 'political' is entirely unhistorical' (Bryan 2005:27; see also the arguments in Punt 2015:89-106). Price (1984:237) argues, 'A Christianizing theory of religion which assumes that religion is essentially designed to provide guidance through the personal crises of life and to grant salvation into life everlasting imposes on the imperial cult a distinction between religion and politics.'

18.In general, a sensible display of courtesy, showing and (perhaps as important) being seen to show respect, went a long way towards establishing concord both with other gods (who, if angered, could be dangerous) and with their humans (ditto)' (Fredriksen 2006:591).

19.A notion underwritten by the frequent references to the unacceptable practices (primarily of not showing deference to Roman gods) rather than improper belief, reasoning or philosophy: 'So, for pious Romans, Christians who refused to sacrifice were evidently atheoi - atheists' (Bryan 2005:118). 
The intertwined and co-constitutive nature of 1st-century religion and politics meant that political power and position were appropriated as divinely sourced and maintained, and that divine contribution, in return, required honour and respect through religious worship of some sort. Those who were unwilling to participate (sacrifice) in Roman religions, were branded as atheists and seen as security threat so that periods of Christian persecution coinciding with Empire's troubled times were hardly coincidental. ${ }^{20}$ Imperial decline was put before the door of those unwilling to participate in the religions sanctified by Empire. Therefore, at times, the need arose to remove the religious wayward to ensure the prosperity of the Empire. Following the relative peace the Early Church enjoyed, it was the later times of Decius, Valerian and Diocletian and thus the times of political, military and economic troubles for the Empire, that delivered the most vicious persecutions for the church - until the church eventually persuaded the Roman emperors that this new religion rather than the gods was religio and not superstitio $^{21}$ (Bryan 2005:118-119; Fredriksen 2006:602-605).

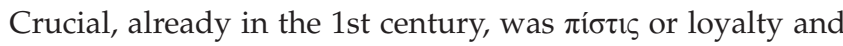
faithfulness to the gods and to the civic institution, exactly in their inter-sectionalities.

\section{Paul's ríotıৎ}

Paul used words from his immediate cultural setting, heavily influenced by Hellenism and indebted to Roman imperialism, with the result that much of his vocabulary had political and social connotations. ${ }^{22}$ The LXX also informed Paul's vocabulary, and sometimes it is not clear whether his words carried Israelite or Greek and Roman connotations. ${ }^{23}$

\section{Development of a notion}

Today's English terms belief and believe, in the first place, indicates conviction, considering something authentic, and, secondarily, trust or confidence in someone or something, but these terms do not include the notion of loyalty and fidelity. For Paul the opposite was true: $\pi i \sigma \tau ı$ and $\pi \imath \sigma \tau \varepsilon v \omega$ was primarily about loyalty and fidelity, even if it also included notions of trust, confidence and conviction (Zerbe 2012:45-46). ${ }^{24}$

20.The unwillingness of Christians to participate in Roman sacrifices, largely in the various forms of emperor worship, meant that they were a threat to the complex and fragile balance of power existing between gods and state (Heyman 2007). The and fragile balance of power existing between gods and state (Heyman 2007). The non-participation of Jesus followers in these sacrifices, when, for example,
processions passed by their homes, publicly exposed them (cf. Fiensy 2004:53).

21. Until the end of the Roman Empire the tensions remained with Roman religion as force that kept on challenging Christianity. This was evident in the position of the erstwhile convert and the apostate emperor, Julian (361-363 CE). It was also
the evident in Augustine's protest in City of God that the fall of Rome to Alaric the evident in Augustine's protest in City of God that the fall of Rome to Alaric the
Visigoth in 410 CE was not because Rome had forsaken its gods (Bryan 2005: 118-119)

22. Some scholars see such resonances between Pauline vocabulary and the socia context as deliberate (cf. Zerbe 2012:8). Zerbe's point on the political embeddedness of 'pistis' is useful, but his emphasis on Pauline subversiveness as the sum-total of Paul's position is not nuanced enough, as explained below.

23.'From the LXX of this psalm [87] (especially v. 5, Gk mētēr Siōn, "mother Zion") is derived in part from the NT concept of citizenship in the heavenly city, "Jerusalem above" (Gal 4:26; cf. Phil 3:20; Heb 12:22; Rev 3:12; 21:2, 9-27; 22:1-5)' (Bruce 1992:1048).

24.Martin's argument (2005:15) in a different context is also applicable here: 'in order to define words we must look, at least to a significant degree, to the "ordinary", "everyday" uses of the word".
In classical Greek usage, words with the $\pi \iota \tau \tau$-lemma were not religious terms - at least not in the sense religion is understood

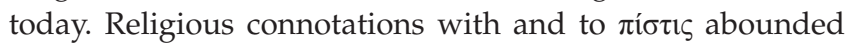
though, so that, for example, loyalty to a socio-political authority was a religious duty, faithfulness was linked to

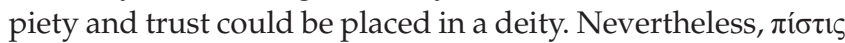
was not used to denote a basic relationship with God. At best, people would rely on deities or trust in deities and their communications. In the Hellenistic period, in philosophical circles the distinctive nature of belief in God was addressed in dialogue with scepticism..$^{25}$ Certainty came to be seen as something given by the deity, but as related to piety as well as a broader belief in or awareness of the ethereal. Belief, which now slowly also came to include notions such as the soul's immortality, participation in the divine world and a final judgement, was seen to imply certain conduct. A good

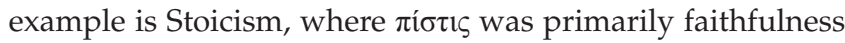
to the self in the sense of integrity of character, which enabled faithfulness to others. God was seen as $\pi$ $\sigma \tau$ ó $\varsigma$ [faithful] which compelled people towards loyalty. The religious nature of

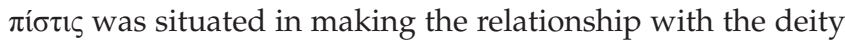
real, rather than as description of such relationship (Bultmann 1985:849).

Gordon Zerbe (2012:36-45) identifies seven important aspects related to how Paul presented $\pi i$ otı as faithfulness or loyalty in his letters. In the first place, God's fidelity is foundational: the provenance of fidelity is the gracious God (cf. Rm 3:2-6) despite the disloyalty or unbelief of people (3:3). Second, Christ was not only the agent of salvation, but also the prototype of fidelity (Gl 1:16; 2:19-20; 3:22; Phlp 3:8-9; Rm $3: 21-22 ; 25-26) .{ }^{26}$ A third aspect of fidelity in Paul's letters

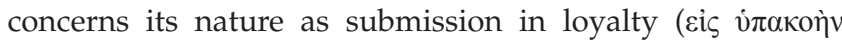
$\pi i ́ \sigma \tau \varepsilon \omega \varsigma$ - Rm 1:5; also 15:13; Phlp 2:6-11). Fourth, for Paul,

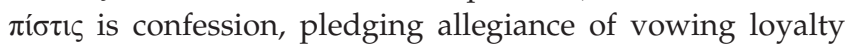

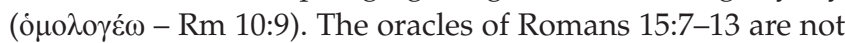
religious liturgies, but songs and praises of homage and loyalty. ${ }^{27}$ A fifth consideration is that Paul, prominently in 1 Thessalonians, referred to those whose allegiance is with

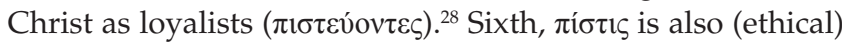
conviction (Rm 14:1, 22, 23) or (personal) belief (e.g. Rm 12:3,

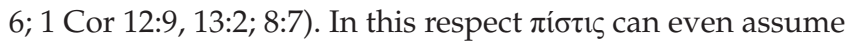
the status of $\varepsilon \dot{v} \alpha \gamma \varepsilon \dot{\varepsilon} \lambda \lambda$ iov itself (e.g. Gl 1:23; 1 Th 2:13). In the

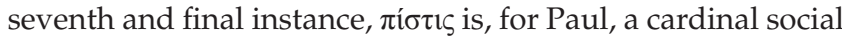
value where fidelity to God also means and implies fidelity to members of the community (cf. Phlm 5).

The orientation of Paul's rhetoric was God's actions involving salvation, justice or righteousness, originating in God's faithfulness. God expressed faithfulness in the faithfulness of

25.Religious propaganda in the Hellenistic period required belief in the proclaimed deities (cf. the Hermetic writings, Odes of Solomon, the papyri, the magical texts, and Celsus; Bultmann 1985:849).

26.'Paul has Christ, through the mouth of David) make his own oath of allegiance to God alone among (and for the benefit of) all the nations (Rom 15:9)' (Zerbe 2012:39).

27.'Paul uses the language of 'swearing allegiance' theo-politically also in Phil 2:10-11 (quoting Isa 45:3), where the outcome similarly entails an act of universal submission in recognition of Messiah supremacy' (Zerbe 2012:41)

28.Interestingly, Paul never used the word roגitns [citizen] (cf. Lk 15:15; 19:14; Ac 21:39; Heb 8:11) 
Jesus (Rm 3:21-26), which called forth the Jesus followers' faithfulness and which included elements such as living in trust and with commitment, showing loyalty and obedience (Rm 1:5). Paul's language reverberated within imperial discourse, which assumed an active role for the goddess Fides among the imperial rulers. ${ }^{29}$ Loyalty promises in imperial discourse required reciprocal pledges and actions, entailing submission to imperial resolve and collaboration with its self-serving rule. In a similar way, Paul declared God's faithfulness, but to purposes different from the Empire's, namely focused on justice for all. Paul called on Jesus followers to align themselves with these purposes to faithfully and loyally join God in striving for justice (Carter 2006:91). The clearest expression of loyalty, and with which Paul's use of $\pi$ í $\tau \iota \varsigma$ resonated, was found in the military context of the 1st century.

\section{Faithfulness' primary context: empire and the military}

Loyalty or faithfulness was an important 1st-century value and moral choice. Individual loyalty was important, but it operated mostly within the broader community of 1st-century collectivist life. In the Hellenistic Roman society, social formations were neither isolated networks existing independently, nor egalitarian. ${ }^{30}$ 'The empire was a single continuous hierarchy, from princeps, to Senate, to Provincial Governors, to cities, to families' (Hollingshead 1998:10). The interrelationship went beyond connections believed to exist from the smallest household to the Empire in its broadest sense. Such interrelationships and the Roman societal context as a whole, formed the operational context for the $\pi i \sigma \tau \imath \varsigma$ rhetoric of the Pauline letters.

Loyalty to the emperor was a general expectation, especially in the army. Life in and loyalty to the army was not an innocuous add-on to lives, but meant the difference between a relatively unworried and a decidedly compromised life. Participation in the army provided a career possibility, building a life and settling down with a generous gratuity upon retirement. In fact, 'everyday service conditions and prospects were far superior to those generally available outside the army' (Kennedy 1992:790-791). Joining the Roman army was restricted to Roman citizens, but auxiliaries comprised many different peoples as well as mercenary forces. 'On being mustered out, usually after twenty years of service, soldiers received Roman citizenship. Thus the army was a major mode of social advancement' (Krentz 2003:348).

In the Roman army, soldiers annually renewed their oath

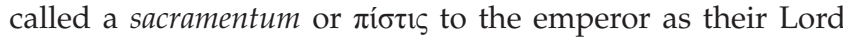
(domus, кúpıs). ${ }^{31}$ Soldiers undertook to serve and be loyal to

29.The emperor embodied Rome's trustworthiness and loyalty regarding treaties and alliances as is clear in Augustus' Res Gestae Divi Augusti (31-34).

30.'[T] he practices of the local household mirrored the relationship of the people to the princeps, and Rome to her gods. The empire was a household, as was the entire cosmos' (Hollingshead 1998:213).

31. As Hobbs explains about high-context societies and the role of metaphor: "the role of metaphor in high context societies is important. Further, this specific metaphor, with its emphasis upon outward symbols of honour (armour), aggressive weapons, obedience to one's commander and suffering for a noble cause, has special significance in a society like the traditional Mediterranean which was populated by persons bound by concepts of honour and shame, and which was structured according to patterns of patronage" (Hobbs 1995:253). the emperor and his associates, follow orders unto death and submit to punishment in the event of desertion and disobedience. The military context - characteristic of the legionary Roman Empire - gave explicit form and substance to $\pi$ í $\tau ı \varsigma$ as loyalty and as a sworn oath..$^{32}$ The oath of loyalty, which soldiers swore to the Emperor and Empire, signalled more than loyalty in battle. ${ }^{33}$ The oath was also exemplary of one of the most severe forms of client-patronage. Through the oath and the commitment it implied, a transition was established from being a civilian to joining military life. A correspondence can be traced between the kind of commitment demanded of the soldier and the warrior of Jesus (Hobbs 1995:257). ${ }^{34}$ Paul's use of military terminology and metaphors (see Punt 2016) is suggestive of the military context as part of the linguistic location for understanding the rhetorical force of $\pi i \sigma \tau t \varsigma$.

\section{Pauline faith or faithfulness? In action ...}

So, what is at stake when $\pi i$ otı is read as faithfulness rather than faith? Faithfulness did not exclude the more conventional notion of faith as conviction. 'Paul's pistis and pisteuein ... have primarily to do with loyalty and fidelity, but are inclusive of trust, confidence and conviction' (Zerbe 2012:26-46,

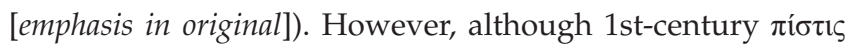
did not exclude convictional faith, even convictional faith should not all too easily be modernised. More importantly,

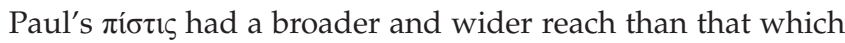
often is accorded our modern religio-theological concept of

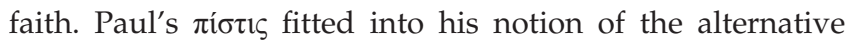
citizenship of Jesus followers - neither of which stood aloof from what today will be called responsible citizenship. He, of course, had to work out the parameters of faithful citizenship, an important element of which was his discursive and ideological opposition to the version fostered by imperial discourse.

\section{Pauline imperial subversiveness: promoting another citizenship}

Paul promoted faithful citizenship among the communities he addressed in a world where politics and religion were mutually constitutive of each other and largely served the same purpose. Ehrman (2008) claims that:

$[G]$ overnment and religion both functioned, theoretically, to secure the same ends of making life prosperous, meaningful, and happy. The gods brought peace and prosperity and made the state great. In turn, the state sponsored and encouraged the worship of gods. (p. 27)

32. Hobbs (1995:255) asserts that "the military metaphor presents a decisive shift in the self-understanding of at least a substantial part of the primitive Christian community', a development or a corrective depending on one's chronology of the New Testament documents.

33.'The soldier's oath of office was a common feature of the Roman army from the republic through to the empire. It ostensibly bound the soldier to his general patron for life. Without taking the oath the soldier could not fight' (Hobbs patron for life. Without

34.In fact, early Christians in the 2nd century and beyond, adopted and outdid the Roman military and gladiatorial sacramentum by their willingness to be burned bound, beaten and slain in demonstrating fides (Barton 1994; cf. Hobbs 1996). 
This much is evident also in Jewish-Roman relationships. The Romans concluded significant agreements with the Jews early in the 1st century CE after the deposition of Archelaus in $6 \mathrm{CE}$ and at the request of the Jews. These arrangements, among others, led to Judea being under direct Roman rule until $39 \mathrm{CE}$. Jews were allowed to practice their religion according to the same guarantees that Julius Caesar and Augustus granted to diaspora Jews earlier. In exchange, Jews sacrificed two lambs and a bull daily for the emperor in the Temple (Philo, Leg. 157, 232, 317; Josephus, War 2.197, 407; cf. Bryan 2005:27). ${ }^{35}$

New Testament texts show various tensions and possibly even subversive notions toward the Roman Empire. ${ }^{36}$ For example, in Mark 1:5 the call for conversion and loyalty to the

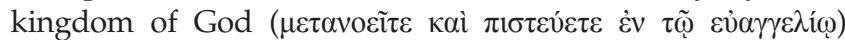
stands in stark contrast to the loyalty expected and sometimes exacted from people by the Roman emperors. From now on,

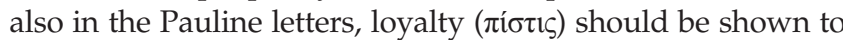
God's kingdom and not those of Rome or the Temple elite. In an analogous way to Roman soldiers swearing and renewing their oath to the Emperor as Lord, the early Jesus followers uttered a similar oath as baptismal confession, 'Jesus is Lord' (e.g. 1 Cor 12:3; Rm 10:9; Phlp 2:11; see Krentz 2003:348).

Such subversion functioned at ideological level. ${ }^{37}$ In the distinction between 'a war of movement' and 'a war of positions', the former is about direct, military or political confrontation, and the latter concerns the struggle for civil society: 'the war of positions is preferably expressed in the confrontation among the different symbolic structures generated in the social space' (Míguez 2012:177, using Gramsci). Incidents from the life of Jesus as portrayed in the Gospels are telling of both his subversive approach to the political authorities of the day such as the triumphant entry into Jerusalem during the time of the Passover festival and the 'cleansing' of the Temple (e.g. Horsley 2008)..$^{38}$

Paul's urban-focussed mission brought him in close contact with the omnipresent imperial tentacles ${ }^{39}$ and his letters'

35.Jewish Christians were not so persecuted, because as Jews their exemption from public cult was ancient, traditional, and protected by long legal precedent (Fredriksen 2006:602).

36.Some scholars oppose the notion that Paul resisted Empire, but sometimes the difference in opinion concerns definitions of terms, for example Harrill (2011:292, [emphasis in original]) contends that 'Transgressive means violating the cultura norms or rules, whereas subversive means actually changing the cultural norm and rules.' However, subversive can also mean creating alternative ideological or discursive practices to challenge the dominant - the sense in which the term is discursive practices to che used here. Further, anti-imperial Thexts such as Thessalonians 4:11: [pay your taxes]? What would the impact of such an attitude have been on discipleship and on citizenship?

37.Fides (loyalty) was one of the many virtues ascribed to Augustus, cited by numerous sources. The others were victoria [power to conquer barbaric peoples and rule over enemies], securitas [security], pax [peace], concordia [social harmony], felicitas [providence or good luck], clementia [grace shown by the victorious over the conquered], iustitia [justice], salus [health], pietas [religious values and piety], virtus [general goodness], and spes [hope] (Elliott \&Reasone 2011:125; Horsley 1997:15-16; Elliott 2008:28-29).

38. Horsley's more general notion (2008) that Jesus deliberately directed a programme of the renewal of covenantal Israel in and across villages, is probably more difficult to show than to claim as the broad canvas for understanding Jesus' work.

39.'Roman cultural hegemony was exercised principally in the cities and their immediate hinterlands. ... Roman rule accentuated rather than broke down the divisions between city and country, rich and poor, local elites and the urban and local masses' (Garnsey \& Saller 1987:203). rhetoric contains sentiments of resisting and subverting Roman ideology. The Pauline de-emphasis on judgement according to works ( $\mathrm{Rm}$ 2:12-16), for example, was heard in an ideological context that celebrated Roman superiority. His

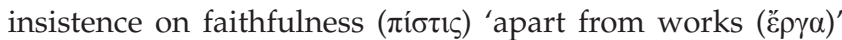
had serious implications in a context of Roman patronage in which the 'works' of benefactors determined people's lives and livelihood - as ultimately underwritten by the emperor as benefactor par excellance who readily claimed his 'works' (e.g. Augustus' Res Gestae). So too, Paul's proclamation of a single ancestor for all people of the world, Abraham as father

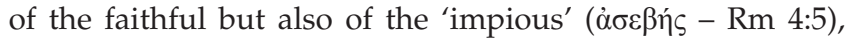
stood askance to a world where imperial ideology relied on the legacy of piety as exemplified in Aeneas' portrayal (Elliott 2007:186; cf. Punt 2010).

A final example: Philippians is politically provocative, similar to Romans, 1 Thessalonians and 1 Corinthians. At once personal and relational, but also political and subversive, it contains those rhetorical trends identified above. ${ }^{40}$ The letter's central exhortation is to sustain unwavering loyalty to Christ and the citizenship or commonwealth established

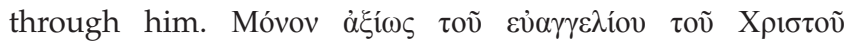
$\pi \mathrm{o} \lambda \iota \varepsilon \varepsilon \dot{\varepsilon} \sigma \theta \varepsilon$ [Specifically, be a citizen body worthy of the good message of Christ] (Phlp 1:27a), Paul wrote, adding also

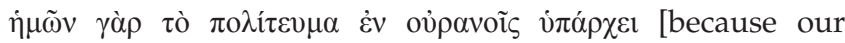
citizenship is in heaven] (Phlp 3:20). Following from this concern, Paul, then, addressed the community's internal life and its citizenship formatted through Christ with lowliness, hospitality and care, and unity as building blocks in contrast to the Roman consumerist, status-focussed, self-promoting glory and general immorality (Zerbe 2012:19).

\section{Hermeneutical implications}

If the argument thus far showed anything, the crucial point is that Paul's 1st-century context differed radically from ours, which rule out simple transferences. This is not to say that Paul's ideas are not worth considering, nor that there is nothing to learn from his letters today. Two issues in particular have become apparent: first, the link between discipleship and citizenship would neither have been surprising, nor uncomfortable for Paul. In fact, at the best of times Paul and other Jesus followers would have found the distinction (not to mention, separation) surprising and uncomfortable. The modern aversion (and rightly so) for any link between politics and religion, to the extent that countries legislate against any involvement between the two, is quite the opposite of the general acceptance in the 1st century that the two belong together. Second, and in close concert with the first, a different notion of religion prevailed at the time: the 1st century's emphasis on ritual, activity and practice over against the 21st century's more affective or even cognitive focus. An emphasis on faith as content and not action would have seemed pointless and maybe as endangering traditional understandings of human relationships with gods.

40.'Philippians is an exhortation (discourse) on the "practice of Messianic citizenship"; (Zerbe 2012:20). 
More specific to Pauline interpretation, a different reading of his emphasis on the theme of citizenship and faithfulness such as proposed here, entails a reappraisal of his focus and what he stood for, and also where he came from. Already in 1977, E.P. Sanders registered 'justification by faith' as a key to Lutheran scholarship rather than a cypher in the Pauline letters. Fredriksen (2014:801-808) argues that, within an apocalyptic stream of 1st-century Hellenistic and Gentileoriented Judaism, the phrase confirms Paul's Jewishness. She maintains that the Second Table of the Law was summarised

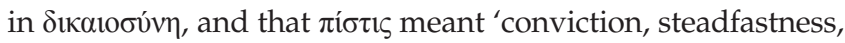
or loyalty' (not 'faith' or 'belief'). She concludes that

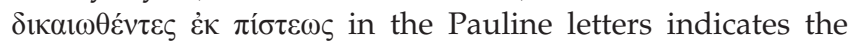
Spirit-enabled ability to act towards each other in community in line with the Torah. Even if one does not accept that Paul promoted the Torah as framework for communal life, Paul's insistence on active faithfulness still indicates a different ground for justification than affective or cognitive conviction.

The Pauline letters' emphasis on faithfulness in concert with citizenship underlines their situatedness in imperial times and the importance of proper analysis of the prevailing and promoted power relationships present in the letters. The hegemonic power and relationships that defined 1st-century life, rear their heads also in the Pauline letters. The ambivalence of imperial contexts and identity configurations is a constant reminder that simple oppositions and contrasts are interpreters' constructions rather than historical situations. Rather than categorical distinctions and oppositions, hegemonic power contributed to the hybridity and mimicry typical of life in imperial times. The Pauline letters point beyond a simple position of either fight or flight towards Empire. Notwithstanding their subversive undertones, the letters do not appear to recognise their complicity in a rhetoric or ideological discourse perched on power relations. ${ }^{41}$ Pauline promotion of citizenship and loyalty not only built upon contemporary military metaphor, but by invoking the ethos of soldiers' commitment through the oath of loyalty ( $\left.\pi i \sigma_{\tau} \downarrow \varsigma\right)$, a vital change happens in the early Jesus communities' self-consciousness (Hobbs 1995:257). ${ }^{42}$ Rather than balancing faithful discipleship and loyal citizenship, Pauline rhetoric advances faithful citizenship, that is, members of Jesus communities immersed in the political, religious and cultural dimensions of the contemporary world as loyal followers of Jesus.

\section{Conclusion}

The danger of not studying and therefore not accounting for the socio-historical context of the New Testament texts in their interpretation is plural. Texts are not read for their

41.The relationship between language and social and cultural context, and also between social context and its social systems, means that lexical choice is never without context or general, but reveals the social values and self-identification of groups (Hobbs 1995:255, referring to Bernstein). As Martin (2005:17) argues, 'The goal of the historian becomes not the conscious or even unconscious intentions of the author but the larger matrix of symbol systems provided by the author's society from which he must have drawn whatever resources he used to "speak his mind".'

42.Jacobs-Malina (1993:12) argues, referencing Mk 1:1-20, "the ideal wife was expected to demonstrate commitment to her husband is the degree to which both male and female believers are expected to commit themselves to God'. The male, public and honour-bound counterpart for such commitment was embodied and public and honour-bound counterpart for such commitment was embodied and
exemplified in the oath of loyalty soldiers swore in the military (Hobbs 1995:257). meaning, but have to toe the interpreters' theological line. In other words, secondary interpretive frameworks, however valuable and constructive in themselves, dominate and drown out textual and socio-historical emphases. In addition, the values of (post)modern society, notions such as equality, democracy, human dignity, are all too easily presupposed to have been the ideals also of ancient people. Neglecting sociohistorical contexts in the interpretation of texts, especially theological texts, leads to anachronism in the absolute sense of the word by postulating a 'general human being', considering all people of all times and of all geographical contexts to subscribe to the same norms, values and morals. This article attempted the opposite and, at the same time, avoided reducing citizenship to primarily a (material) matter of taxes, civic processions, political canvassing, and military and civic service.

\section{It is a tragedy that (Zerbe 2012):}

in the comfortable, symbiotic dualism of later Christendom, heaven became the soul's spiritual homeland and destination, whereas the empire could claim the full allegiance of the embodied person on earth. (pp. 5-6)

When it came to life in Empire, what did faithful discipleship and responsible citizenship look like for the Pauline communities? On the one hand, 1st-century people would not have found the juxtaposition troubling - maybe just tautological and the use of two phrases redundant. On the other hand, the Pauline letters are evidence of efforts to sustain both the categories of what we would call discipleship and citizenship today, and also of some tensions involved, in the end promoting faithful citizenship: loyal commitment to Jesus as lifestyle and not only or simply conviction - faithful citizenship in God's heavenly city on earth.

\section{Acknowledgements}

This article was submitted in appreciation for Jan van der Watt's contribution to NT scholarship in South Africa and elsewhere.

\section{Competing interests}

The author declares that he has no financial or personal relationships which may have inappropriately influenced him in writing this article.

\section{References}

Barton, C.A., 1994, 'Savage Miracles: The Redemption of Lost Honor in Roman Society and the Sacrament of the Gladiator and the Martyr', Representations 45, 41-71, Winter.

Bruce, F.F., 1992, 'Citizenship', in D.N. Freedman (ed.) The Anchor Yale Bible Dictionary, vol. 1, pp. 1048-1049, Doubleday, New York.

Bryan, C., 2005, Render to Caesar. Jesus, the Early Church and the Roman Superpower Oxford University Press, Oxford.

Buell, D.K., 2002, 'Race and Universalism in Early Christianity', Journal of Early Christian Studies 10(4), 429-468.

Bultmann, R., 1985, 'pisteúō [to believe, trust], pistis [faith, trust], pistós [faithful, trusting], pistóó [to make someone trust], ápistos [faithless, unbelieving], apistéō [to disbelieve, be unfaithful], apistía [unfaithfulness, unbelief], oligópistos [of little faith], oligopistia [littleness of faith]', in G. Kittel, G. Friedrich \& G.W. Bromiley (eds.), Theological Dictionary of the New Testament, pp. 848-857, Eerdmans,
(ittle faith], oligopistia [littlenes Grand Rapids. 
Carter, W., 2006, The Roman Empire and the New Testament: An Essential Guide, Abingdon, Nashville. (Abingdon Essential Guides).

Crossan, J.D. \& Reed, J.L., 2004, In Search of Paul. How Jesus's Apostle opposed Rome's Empire with God's Kingdom: A New Vision of Paul's Words and World, HarperSanFrancisco, New York.

Ehrman, B.D., 2008, The New Testament: A Historical Introduction to the Early Christian Writings, 4th edn., Oxford University Press, New York.

Elliott, N., 2007, 'Political Formation in the Letter to the Romans', in R.L. Brawley (ed.), Character Ethics and the New Testament. Moral Dimensions of Scripture, pp. 179-90, Westminster John Knox Press, Louisville.

Elliott, N., 2008, The Arrogance of Nations. Reading Romans in the Shadow of Empire, Fortress, Minneapolis. (Paul in Critical Contexts).

Elliott, N. \& Reasoner, M. (eds.), 2011, Documents and Images for the Study of Paul, Fortress, Minneapolis.

Fiensy, D., 2004, 'The Roman Empire and Asia Minor', in S. McKnight \& G.R. Osborne (eds.), The Face of New Testament Studies: A Survey of Recent Research, pp 36-56, Baker Academic, Grand Rapids.

Fredriksen, P., 2006, 'Christians in the Roman Empire in the First Three Centuries CE' in D.S. Potter (ed.), A Companion to the Roman Empire, pp. 587-606, Blackwell Companions to the Ancient World, Blackwells, Malden.

Fredriksen, P., 2014, 'Paul's Letter to the Romans, the Ten Commandments, and Pagan "Justification by Faith"', Journal of Biblical Literature 133(4), 801-808.

Garnsey, P. \& Saller, R., 1987, The Roman Empire: Economy, Society and Culture, Duckworth, London.

Harrill, J.A., 2011, 'Paul and Empire: Studying Roman Identity after the Cultural Turn', Early Christianity 2(3), 281-311.

Heyman, G., 2007, The Power of Sacrifice: Roman and Christian Discourses in Conflict Catholic University of America Press, Washington.

Hobbs, R., 1995, 'The Language of Warfare in the New Testament', in P.F. Esler (ed.), Modelling Early Christianity: Social-Scientific Studies of the New Testament in It Context, pp. 248-262, Routledge, London, New York.

Hollingshead, J.R., 1998, The Household of Caesar and the Body of Christ: A Political Interpretation of the Letters from Paul, University Press of America, Lanham.

Horsley, R.A., 1997, 'The Gospel of Imperial Salvation: Introduction', in R.A. Horsley (ed.), Paul and Empire: Religion and Power in Roman Imperial Society, pp. 10-24, Trinity Press International, Harrisville.*Horsley, R.A., 2008, 'Jesus, the Messianic Traditions of Israel, and the Underground of Galilee', paper presented in Brazil.

Jacobs-Malina, D., 1993, Beyond Patriarchy: The Images of Family in Jesus, Paulist, New York.
Kennedy, D., 1992, 'Roman Army', in D.N. Freedman (ed.), The Anchor Yale Bible Dictionary, vol. 5, pp. 789-798, Doubleday, New York.

Kreitzer, L.J., 1993, 'Kingdom of God/Christ', in G.F. Hawthorne, R.P. Martin \& D.G. Reid (eds.), Dictionary of Paul and His Letters, pp. 524-526, IVP, Downers Grove.

Krentz, E., 2003, 'Paul, Games, and the Military', in J.P. Sampley (ed.), Paul in the Greco-Roman World: A Handbook, pp. 344-83, Trinity Press International, Harrisburg.

Lipka, M., 2009, Roman Gods: A Conceptual Approach, Brill, Leiden. (Religions in the Graeco-Roman World, 167).*Martin, D.B., 2005, 'Introduction', in D.B. Martin \& P.C. Miller (eds.), The Cultural Turn in Late Ancient Studies: Gender, Asceticism, and Historiography, pp. 1-21, Duke University Press, Durham \& London.

Míguez, N.O., 2012, The Practice of Hope. Ideology and Intention in 1 Thessalonians, Fortress, Minneapolis. (Paul in Critical Contexts).

Perkins, J., 2009, Roman imperial identities in the Early Christian era, Routledge, London. (Routledge Monographs in Classical Studies).

Price, S.R.F., 1984, Rituals and Power: The Roman Imperial Cult in Asia Minor, Cambridge University Press, Cambridge.

Punt, J., 2010, 'Empire as Material Setting and Heuristic Grid for New Testament Interpretation: Comments on the Value of Postcolonial Criticism', HTS Teologiese Studies/Theological Studies 66(1), 1-7, Art \#330. https://doi.org/10.4102/hts. Studies/Theo

Punt, J., 2015, Postcolonial biblical interpretation: Reframing Paul, Brill, Leiden. (STAR, 20).

Punt, J., 2016, 'Paul, military imagery and social disadvantage', Acta Theologica suppl ser. 23, 201-224. https://doi.org/10.4314/actat.v23i1S.10

Stowers, S.K., 1995, 'Greeks Who Sacrifice and Those Who Do Not: Toward an Anthropology of Greek Religion', in L.M. White \& O.L. Yarbrough (eds.), The Socia World of the First Christians: Essays in Honor of Wayne A Meeks, pp. 293-333, Fortress, Minneapolis.

Strootman, R., 2014, 'Hellenistic Imperialism and the Ideal of World Unity', in C. Rapp \& H.A. Drake (eds.), The City in the Classical and Post-Classical World: Changing Contexts of Power and Identity, pp. 38-61, Cambridge University Press, Cambridge.

Versnel, H.S., 2011, Coping with the Gods: Wayward Readings in Greek Theology, Brill, Leiden. (Religions in the Graeco-Roman World, 173).

Woolf, G., 2012, Rome: An Empire's Story, Oxford University Press, Oxford.

Zerbe, G., 2012, Citizenship: Paul on Peace and Politics, CMU, Winnipeg.

Keywords: Pauline letters; Faithfulness; social responsibility; Empire; politics; citizenship 